\title{
[5]
}

\section{Working for a Living}

This chapter begins with a description of working-class occupations in Taiwan and then introduces two women, Guo A Gui and Lo A Lan. After I give brief sketches of these people as I saw them, each recounts her own life history. Miss Guo and Mrs. Lo, chosen to illustrate the theme of "working for a living," have held many manual and service jobs but have never been employed in any of the more secure and well-paid worker occupations. Other life histories will reveal additional work experiences, just as these two inform us about family life, female-male relationships, and other themes taken up in later chapters. The lives of Miss Guo and Mrs. Lo are particularly appropriate as illustrations of work life, however, because they show so effectively the poverty that punishes weakness, failure, or ill fortune in societies like Taiwan's. Fear that they or their children might find themselves in such a position motivates much of the industriousness with which most Chinese approach their work.

\section{Business and "Bitter Labor"}

Work is essential to life for most of Taiwan's people. Many shopkeeping households are open for business from early morning until everyone goes to bed at night; some never take a holiday, even at the New Year. Factory workers put in six or seven days a week, often at more than eight hours daily (Diamond 1979:322) - eighteen in some small owner-operated factories (Niehoff 1987). Taxi drivers drive till they drop, often for sixteen hours in heavy smog and dangerous traffic. Much manual work is either physically exhausting, like the pedicab driving, which, until the late sixties, provided 
much public transportation in Taibei, or it is deadeningly boring, like the decoration of millions of sheets of imitation paper "spirit money" burned at religious celebrations, or the factory assembly of microscopic electronic parts. Work, for the poor, takes up most of each day, and often pays badly. Although workers know they must work, and hard, they cannot be said to value work for its own sake. People, when they have choices, choose jobs for their rewards: ample leisure, if possible, a good wage, few physical demands, and the opportunity to control their own time and effort (Harrell 1985).

Although the growth of mining, the handicraft industry, and commerce slowly created more varied jobs in the nineteenth century, agriculture remained the main occupation of more than half of Taiwan's people until 1958 (computed from DGBAS 1974: Tables 18 and 22). The modern industrial boom of the 1960s tipped the balance from a primarily agricultural to a primarily nonagricultural economy. By 1983 only about one-third of families were registered as farming households (DBGAS 1981, Supplementary Table 11), and many of their members worked at nonagricultural jobs.

Until recently, most farmers in Taiwan grew rice or a combination of rice and sugar, with a few subsidiary cash crops. Unmechanized rice and sugar agriculture uses a great deal of labor under extremely uncomfortable conditions. Wet rice growing requires many hours spent knee-deep in muddy water: planting, weeding, spraying with dangerous insecticides, adjusting water levels, and mending irrigation dikes. When harvest is near and the fields are dry, hand cutting, carrying, threshing, drying, and storing of grain call for major physical efforts, especially when rain threatens the harvest. Sugar growing is notorious for extremely heavy labor in cutting and carrying huge bundles of cane from the fields. Taiwan's generally high heat and humidity make such labor even harder, adding the dangers of heat prostration to other work-related ailments such as hernia, varicose veins, back trouble, and snake-bite. It is not surprising that many people prefer other kinds of work when it is available.

The economic rewards of farming depend on the relationship of the worker to the land. A day laborer working for wages, a tenant who sharecrops for someone else, a family that owns enough land for its own members to work, and a landlord who employs others or leases land to tenants receive very different compensation from their work. Although the land reform of the early fifties eliminated big landlords and decreased the proportion of tenants to about one-sixth of all farmers (computed from DGBAS 1981: Supplementary Table 5), there are still landless migrant workers who follow the harvests. Except for the large tracts owned by such state enterprises as the Taiwan Sugar Corporation, most farms are now run 


\section{Chinese Working-Class Lives}

by owner-operator families whose adult men and younger members increasingly find nonagricultural work, leaving the farming to wives, children, the elderly, and hired labor.

Agriculture-even with Japanese innovations such as foot-pedal rice threshers, new irrigation systems, and narrow gauge railroads for sugar transport, and those that have been implemented since the 1970s, especially motorized plows, threshers, and vehicles-remains a physically taxing undertaking. Even with the Nationalists' improvements-land reform, wider rural electrification, some farm mechanization-life for most farmers has fallen behind that of nonagricultural households in standard of living and difficulty of work. Most rural young people seek opportunities to leave farming for easier and better-paid jobs in livelier town or city settings.

Because of the island's small size and good communications and its people's entrepreneurial skills, rural Taiwanese have founded multitudes of small new businesses in the countryside-frame knitting, tile manufacturing, plastics injection (Harrell 1982; Niehoff 1987; Stites 1982)-while larger enterprises have been encouraged by the availability of cheap rural labor to set up factories there as well. Although the gap between cosmopolitan Taibei and a rice-growing village seems great to their respective inhabitants, virtually the same working-class jobs have been accessible to rural as to urban folk since the mid-1960s. A job almost anywhere in the island's more densely settled western half can be combined with at least part-time residence in the worker's family home base, wherever that might be; by express train, the island's two biggest cities, Taibei and Gaoxiong, are only four hours apart. Farm families, then, are no longer sharply distinguishable from urban ones, while at the same time agricultural work is easier to escape from than it was when our subjects were young.

None of the subjects of these life histories is a farmer, though many, like Miss Guo and Mrs. Lo have done farm labor, and most can trace their families back to agriculture. In this, they represent the general experience of Taiwan's people today-connected to farming life by memories and relatives, but personally free of its drudgery, and glad to be so. Instead, they engage in such typically working-class occupations as manual labor, factory work, service work, military service, and small-scale manufacture, commerce, and house renting.

At the bottom of this occupational scale is the hard manual work, such as digging building foundations with shovels or carrying concrete in buckets, which the Chinese describe as $k u$ gong, "bitter labor." Such work, more common in the past, is today being replaced more and more by mechanical methods. Because most households in Taiwan now have some form of piped running water, water carrying, a common occupation of poor men in the 
past, is no longer necessary. Large modern buildings in Taiwan are now built with complex cranes and cement mixers; but on small ones, women like Mrs. Lo still carry buckets of concrete up shaky ramps all day long for the price of a few meals. Though there is far less of it now, unskilled construction work, stevedoring, street cleaning, the emptying of privies, and agricultural migrant labor still employ perhaps 10 percent of the labor force in "bitter labor."

Service work is another area of occupation: about 15 percent of Taiwan's work force is employed this way (estimated from 1981 DGBAS data). Service workers include domestic servants; restaurant, hotel, retail, and similar personnel; and entertainers, including the large number of bar girls and prostitutes Taiwan's militarized economy has encouraged. Like "bitter labor," service work is disliked because the hours are long, it pays poorlyusually less than factory work-and it requires so much deference to the employer or customer. Chinese servants are usually on call twenty-four hours a day, with only one or two days off a month, and often they must tolerate considerable abuse. Service employees such as the young saleswomen in large department stores are also kept on long shifts and low wages, and are required to perform much "emotional labor" (Hochschild 1983), flattering and cajoling customers to buy. Older women frequently must depend on service work if they want to earn an income but have no capital to begin a business of their own.

Modern industrialization has created a wide range of manufacturing jobs in which human effort has been largely replaced by machines, employing people who in the past either found no income-producing work or who worked on farms and in small handicraft workshops. Jobs in big, exportoriented factories are eagerly sought, especially by young women and men in their teens. Easier than "bitter labor" because it is indoors and physically lighter, factory work also pays better, as machine-assisted productivity is so much greater than that of hand labor.

Because about half of all factory workers are between the ages of fifteen and twenty-four, with few in the older ages (Gates 1979:395), our subjects, nearly all of whom are older people, mention factory work only in passing or as an occupation of their youth-like Miss Guo-or of young relatives. In today's economy, however, they are an extremely important group, for it is with their labor that Taiwan's "economic miracle" has been built.

The young women who make up one-third of this important work force (Taiwan Provincial Labor Force Survey and Research Institute 1971:50) have been described by Linda Gail Arrigo (1980, 1984), Norma Diamond (1979), and Lydia Kung (1983, 1984). Kung especially gives us a very full picture of the lives of women industrial workers in the mid 1970s. For rural 
youth, who make up a large proportion of factory workers, these jobs at first also have a certain glamor because of the independence they appear to offer (Kung 1983:72-73).

Such factories actively recruit young women from the countryside, providing them with inexpensive barrackslike housing, canteens, limited medical services, and some recreational activities (Kung 1983:109). Others live with relatives or in cheap rented rooms in the poorer neighborhoods and suburbs (Arrigo 1984). While some young people appear to enjoy the opportunity to leave home and escape parental restraint on their daily activities, others become homesick or disillusioned with the dull work routines, the limited opportunities for advancement, and the unpleasantness resulting from dishonesty, sexual exploitation, and insincerity. Young women especially complain that these factors add up to a new understanding that life "out in society" is unpleasantly "complicated," fuza, a term that people often contrast with the simplicity or straightforwardness of family, school, and village life (Kung 1983:159-64).

The dangers of factory life are not merely social, however. Some worksuch as assembling microchips-is widely believed to result in rapid deterioration of eyesight, while many factory hands are exposed to unguarded machinery and toxic substances. In 1975 a worker in an asbestos-weaving factory told Linda Arrigo (1980:31): "Your whole body gets covered with asbestos fluff. . . . There is no air-conditioning, and in the summer you are sweaty and sticky over your whole body. The company says they can't put in air-conditioning because the fiber is too damp and the air-conditioners would get clogged." Asbestos, of course, causes both asbestosis and cancer.

Factory work offers young people from poor families an opportunity to earn money for various purposes, including their own educations. The goal of completing high school at night while working to pay the fees their families cannot afford is common especially among woman workers. While some succeed in this attempt, many find the pressures of work, study, and dormitory life too much, and give it up before graduation (Kung 1983:155). Many parents of unmarried factory workers expect their children to remit all their wages but pocket money to pay family expenses, including school fees for brothers of working daughters (Kung 1984:112). Some are less likely to comply with these demands, but daughters often feel they have no choice, for they and their families believe girls should repay the costs of rearing them before they marry (Greenhalgh 1985c). As one of Kung's (1983:119) informants exclaimed: "What's the good of having a daughter if she doesn't bring any money home?" A recent study shows that girls in one factory-oriented rural community are receiving fewer years of education, as they begin outside work at younger and younger ages (Niehoff 1987). Wages 
are low-U.S. $\$ 25$ a month was a common wage in the late sixties, and in the early eighties, the going wage had reached only about U.S.\$150. Such an income provides only a meager living for a single person-not enough to give the sense of freedom that many young people hope to find outside the family.

The women Kung describes belong to a company union that collects dues but provides almost no services in return. As one remarked, "The way I see it, the managers of the company are the ones who run the union, and they have the final say. Their interests and ours are different, and naturally they'd look after their own concerns and not give much attention to what we want" (1983:108; see also Stites 1985:227-46).

Since the industrial boom of the late 1960s-although about one-fifth of the work force works in large industrial enterprises (estimated from DGBAS 1981 data)-factory work is rarely a lifelong occupation. Factories generally discourage the employment of married women, as does the typical Taiwan pattern of rapid childbearing right after marriage. Men withdraw from factory employment as they mature because factory wages are rarely adequate for a growing family and because the discipline and routine become increasingly hard to bear (Stites 1982). As many as can, find other kinds of work - very often as small, independent businessmen (Stites 1982; Harrell 1985). As women round out their families and consider returning to income-producing work, they too look for opportunities outside the factory system. Many start small shops or restaurants, work parttime as servants or service personnel, or finish products at home for larger industries.

Factories, then, are operated by a part-time proletariat of young people, soon replaced by another generation of docile teenagers who will work for little more than it takes to support one person. In recessions, these young people are easily laid off, and return to work in their families farms and small businesses. Their rapid movement into and out of factory work has been a great advantage to factory owners, Chinese and foreign: this cheap and flexible labor supply does not bargain, strike, bring political pressure to bear, or even settle down in working-class neighborhoods near the factories. Such a group does not directly reproduce the next generation's industrial workforce, but depends on the existence of a large small-farm, smallbusiness sector whose sons and daughters "enter society" temporarily during their youth to work in factories. They then return to found or continue family enterprises whose sacrifices of time, energy, equality for women, and heavy discipline of the young benefit not only themselves, but also the big industrial sector (Gates 1979).

An unusually large working-class occupation in Taiwan is military service. 


\section{Chinese Working-Class Lives}

Under Nationalist rule the island has for many years supported one of the largest standing armies in the world. Most of its enlisted men were young draftees, serving three (or since 1973, two) years, beginning at age eighteen. This prevents working-class young men from taking up training or permanent employment until their enlistment is over, which delays marriages and encourages some to become the temporary factory labor on which industry relies.

The regular army, however (as well as the air force, navy, and marines) is staffed with a very high proportion of older men who came from the mainland with Jiang Jieshi. Many, now retired, receive pensions and other benefits from the central government. The wages of even the regular and retired military personnel, if they are of low rank, are below those of factory workers and insufficient to support and educate a family. But they receive other benefits: free medical care for themselves and their families at veterans' hospitals and-like all government employees - monthly rations of rice, salt, oil, and fuel. Some receive housing and additional benefits for dependents; sons are often given unofficial preference in military advancement, and many who have retired since the mid-1960s, like Mrs. Lo's husband, have been employed in government organizations and enterprises. Those who retired or were demobilized in the fifties, however, often received no help at all from the government in making a new life in Taiwan. Some old Mainlander retirees have nothing to rely on except the rather grim veterans' homes. But, while even low-ranking Mainlander servicemen have had certain advantages, they increasingly find themselves competing on disadvantageous terms in an economy for which their lives in the service have not prepared them well. They and their families depend more and more on working-class jobs to survive.

It is unusual to refer to soldiers as members of the working class. Except for occasional emergencies, for example, after typhoons and floods when soldiers are brought in to repair roads and irrigation systems or to save crops, they are not part of society's productive labor force. By now, however, most of the original mainland soldiery has retired into typical working-class jobs, and many of their children have entered the working class as well. Career military service at the enlisted level is often seen as a Mainlander occupational specialization; it produces a level of living comparable to that gained in factory work.

Except for a career in the military, in which some Mainlanders take considerable pride, the working-class jobs discussed so far are not generally seen as very desirable except as an escape from the even greater drudgery of farm labor. A great many working-class people, however, hope to achieve a more valued occupational goal: to become the owner of a small business. 
It is hard to exaggerate just how small these enterprises can be. A Chinese folk story tells of a rich man who began his career by buying five peanuts for a single small coin, and selling them for two. While I never saw quite such commercial miniaturization in Taiwan, there were, and still are, many businesses that start with a minimum of capital. The sellers of "shoulder pole noodles," well known in Tainan City, carry an entire restaurant-stove, cookpot, ingredients, dishes, and a stool for the customer-in two boxes slung on a shoulder pole, from which they produce bowls of delicious noodle soup for the comfortably waiting buyer. The late evening streets of all of Taiwan's cities swarm with slightly larger versions of these portable restaurants, usually mounted on bicycle-powered carts. For a small fee, they plug into an electrical outlet in a nearby house, turn on the bulb, and set up shop for the strollers who emerge in the cool evening to enjoy cheap snacks and the gaiety of the promenading crowd. A former army man in Prosperity Settlement makes his small family's living with a grindstone and emery paper, polishing the rough edges from newly moulded U.S. Army good-conduct medals. In 1968 a common sight at the entrances to city markets was a young girl with a magnifying glass, mending runs in nylon stockings.

Many small businesses are more substantial: rice-milling shops are ubiquitous in Taiwan, as are tailoring establishments, barber shops and beauty parlors, grocery stores, photographers' studios, and a multitude of tiny factories that produce everything from bean curd and incense sticks to electronic subassemblies for bigger factories. In the late sixties I lived near a household whose members bought used light bulbs door-to-door, smashed out the glass and inner works, dipped the brass bases in acid baths to repolish them, and sold them back, in great, glittering festoons, to a light bulb factory.

Many of the more complex traditional handicraft industries, such as those where the craftspeople make elegant hardwood altar tables, carve images of gods, and tailor are learned first by apprentices who later become skilled journeymen working under master craftsmen with their own shops. These independent-minded workers travel from shop to shop, rebellious against discipline and willing to forgo high earnings for plenty of leisure and a good time. Eventually, however, most hope to set up their own shops as masters (de Glopper 1979).

Most small businesses are run by families using family labor, young apprentices from related or neighboring households, and sometimes a few hired hands. The businesses occupy the front of the house in which the family lives, and are attended to by family members in between other activities such as housework and baby care, school attendance and home- 
work, watching television and entertaining visitors, shopping for stock or selling products. People in such businesses work hard, but they can also take a day off for illness or a funeral, rest or nap when the heat is unbearable, go to the bathroom without having to ask permission, and have the kinds of control over their own actions which factory conditions are designed to prevent. Such reasons are often cited for the popularity of small businesses.

The economic basis of small business is different from factory work as well. In a family enterprise, as in a farm household, the family, not the individual, is the significant unit. Family members do not receive wages but draw on household funds, usually managed by the wife or mother-inlaw, when they need money. She may also regularly distribute a little pocket money for cigarettes, snacks, or movies. Household members work at jobs for which their talents and other commitments suit them, not for the short-run reward of wages but for the long-term good of the family. If jobs are plentiful "outside" and pay better than the value a member can contribute at home, the family urges her or him to look for work and mobilizes its network of contacts to help find it. When a family member working "outside" is laid off, she or he returns home and expects to be reabsorbed into the family economic unit.

Such small businesses are well suited to Taiwan's expanding economy; in 1973 enterprises with fewer than ten workers made up 90 percent of all businesses (DGBAS 1974: Table 230), though this percentage has been diminishing in recent years. ${ }^{1}$ Such enterprises are rational and positive adaptations to Taiwan's economy because they use labor in a flexible and inexpensive way-people in them work hard and long, sometimes only in return for simple shelter, food, and clothing. In prospering households, they will receive a more comfortable standard of living - even luxuries such as a higher education-and sons will receive shares in a growing investment of capital in the house and business.

The experience of Mr. Kho, whose life history is detailed in Chapter 7, tells us what can happen when a small-scale family business expands and becomes successful. He was able to educate one son, now a professional in a related field and living elsewhere, while the other son, still living with his father, continues as a small contractor. Mr. Kho's general-goods store is managed by his daughter-in-law, and the whole family has gained financial advantage from the rents that come from his final large investment, the

1. Because of changes in government statistical categories, it is not possible to calculate the 1980 figure for these very small businesses. 
apartment building he built and retired to. This family is not rich, but their daughter-in-law can afford a trip to Southeast Asia.

By contrast, the family of Mrs. Lim, whom we will meet in Chapter 9, runs a house-front shop that was only very modestly successful for years as an electrical repair business and that now does a little better as a fruit-andice shop. They hope that training a son to bake bread will improve business enough through diversification, provide work at home for one of the underemployed daughters, and enable one of the sons to support a wife. Miss Ong's picture-copying business (see Chapter 6), for which no one else in her family is trained, struggles along, dependent on the suitability of her home as a business location.

Through education, some working-class young people escape the necessity of manual labor or shopkeeping by finding white-collar jobs as office workers for the government or large private businesses (I will discuss this much desired occupational shift in Chapter 9). Very few people can achieve such education by their own efforts. An economically stable family that is willing to pay the student's expenses and forgo the labor he could contribute or the income he would otherwise earn is behind most successful whitecollar workers. This pattern has existed for a long time: Mrs. Lim's backing from her educated and prosperous families enabled her to become a schoolteacher; Mr. Kho's respectable farm family encouraged his rise to the position of tea agronomist. The poorest person among our subjects, Mr. Kang (Chapter 6), has no relatives at all in Taiwan to help him. In general, the relatives of people who have been laborers all their lives, like Mrs. Lo, have had little to help them with.

When we examine working-class occupations, we see that the most desirable of them, small business, promises a decent living, often actually provides it, and offers hope that with careful management and the right kind of family a really substantial enterprise, or professional career for the children, can be attained. The values of small-business families permeate the rest of the working class, whose members, despite severe odds, are sometimes able to escape from bitter labor by good luck and adherence to those values. The desire for the independence and social mobility that small businesses make possible motivates the traditionally frugal, savingsconscious, hard-working life style of traditional Chinese families, and explains the deep distress felt by some of our older subjects at what they see as the free-spending, pleasure-loving younger generation. A family whose younger members fail to learn the tough lessons of their parents may indeed cut themselves off from many opportunities. As long as the expansion of the economy continues, however, even the slackers will find jobs to 


\section{Chinese Working-Class Lives}

support themselves. Prolonged economic stagnation or depression would very likely bring rebellious younger folks to a new appreciation of the importance, for working-class people, of the family as a safety net, a critical human resource.

The special place of small business even in the spirit world is symbolized for Taiwanese by a shrine in most places of business to either the Earth God, seen as a god of wealth, or Guan Gong, a god of war among other things. ("Why war?" I asked a shopkeeper. "Because being a merchant is a struggle-it is kill or be killed in business," he replied.) The Earth God is a benevolent-looking, white-bearded old gentleman seated on an imperial magistrate's throne, while Guan Gong, with the brilliant red face of a rough fellow, brandishes both his battle sword and a writing brush for keeping accounts. A foot-high wooden image of one of them, illuminated by red electric lamps, surveys most Taiwanese shops from a rear wall, cajoled by daily sticks of incense and twice-monthly food offerings to bring prosperity to the enterprise.

Working-class families often have several members who work, and consider it ideal that a family's occupations should be varied. A small business managed by the mother and her daughter-in-law, construction work for the husband and eldest son, a job as a clerk in a bank for the better-educated younger son, and a factory place for an unmarried daughter make a nice mix: stability, though low incomes, from shop and clerking, bigger wages, if intermittently, from skilled house building, and a little extra cash from the daughter's paycheck. Many parents deliberately steer offspring into such combinations and readily shift work to seize new opportunities. Although some working-class Mainlanders form small business partnerships for lack of kinfolk with whom to cooperate, the Chinese prefer the family as the basic economic unit. Whether success in life is to be achieved through business or some other route, it is achieved more readily by "pooling and sharing" group resources than by individual effort alone (Wang Sung-hsing 1971).

Even when they do not establish their own businesses, people like to find work near home. If they must go far afield for employment, rather than move their residence, many prefer long commutes or even periods of separation from their families, so that on holidays at least they can return to their "old home." The frequent moves from one city to another that Americans endure for the sake of steady work and career advancement would strike most Chinese as terribly disruptive to the network of human relations that everyone wants to develop. Fortunately for them, Taiwan is a rather small place with good transportation. When the economy is thriving, people can usually follow the employment frontiers while at the same time 
keeping very close ties with a permanent home. Though Taiwanese people have far deeper roots in island communities, even many Mainlanders have by now established such home bases in their adopted province. Military encampments, squatters' areas, and blocks of public housing originally filled with strangers have become neighborhoods, developing gossip grapevines and sometimes holding folk celebrations together. These new communities re-create, often with very heterogeneous populations, the villagelike places where characteristic patterns of social and family relations can thrive.

Rural villages and working-class city neighborhoods contain many workplaces, which are the result of innumerable choices made by people who trust personal over impersonal social relations, prefer self-employment to occupational subordination to others, and, probably quite accurately, suspect "society" of having very little concern for their well-being. Working for a living is risky business.

\section{Guo A Gui: "People Have to Have Fun, Too!"}

Guo A Gui is a native Taiwanese woman in her late fifties whose life has been spent in "bitter labor." Nonetheless, she has managed, through hard work and poor living, to accumulate a little property and become a landlord on a very small scale. Her life story reveals much about working-class Taiwanese life under both Japanese and Nationalist rule. For her, the change of government and the improved economy have not meant a great deal, although some of her misfortunes are the result of accidents that might have happened anywhere. Having entered into a union with a Mainlander who has no relatives or useful contacts, and having failed to produce a filial son of her own, Miss Guo has been unable to build the kind of patrilineal family that would have contributed to her income and given her an easier life. Like many of the women in this study, she has had to depend largely on her own exertions in a society where a woman's efforts do not receive many economic rewards. Despite what she sees as a hard, unfortunate life, Guo A Gui-Cassia Guo-remains cheerful, optimistic, and energetic.

When Miss Guo and I met in the cafeteria where she washes dishes and prepares vegetables, she set out to charm me, making the most of her limited Mandarin and my limited Taiwanese. Flattery, teasing, lessons in Japanese: soon she was interviewing $m e$. When I told her about my collections of life histories, she not only volunteered but promised expansively to help me find many "sufferers" who would tell me how poor people really 


\section{Chinese Working-Class Lives}

lived. She did, too, introducing me into many houses in the squatter settlement in which she lived and inviting friends over to reminisce into my tape recorder. Lo A Lan, whose life story follows this one, was our most frequent visitor and interviewee.

Cassia Guo, Orchid Lo, one of my field assistants, and I sat together in Miss Guo's living room many afternoons, with Mrs. Lo interjecting an occasional episode of her hard history, the assistant and I giggling and taking notes, and Miss Guo getting uproariously, gloriously drunk. Sometimes she insisted that we all go out to meet people under her loud patronage. These outings were awkward for Mrs. Lo, humiliating for my assistant, and immensely revealing for me, as I was literally dragged behind the veil of courtesy and privacy that most Chinese draw around their families in the presence of an outsider.

I reluctantly discouraged these uninvited forays, pointing out that planned visits in which people could comfortably tell their stories were better for making the careful record my work required. Miss Guo acquiesced but reminded me repeatedly thereafter to be less serious about life: "People have to have fun, too!" She seemed to enjoy thoroughly the taping, the questions, the opportunity to expand on subjects of interest to her. While the alcohol she drank-a nasty-smelling medicinal liquor with genuinely unpleasant aftereffects-made for much repetition and sententiousness, it also created the extraordinarily relaxed atmosphere in which these near-strangers recalled their pasts.

Although she was willing to reveal herself in this way in her own house and neighborhood, Miss Guo presented herself much differently when she left the squatter settlement. At work, she dressed neatly, if ungracefully, in loose pants, blouses, and long knit vests; her hair was always tidily crimped; her words were deferential, even if her eyes were often ironic in her dealings with the blustering and nearly incomprehensible Hunan cook she worked under. Walking in the settlement, she would seize my hand as if to stress our friendship to her neighbors, dropping it as we left the area's boundaries where only strangers would observe us. While it was necessary to appear respectable in public, among people who, like herself, had few claims to respectability she could enjoy the undisciplined, emotional side of life.

Old ladies who drink heavily, talk openly about sex, and are bold in their relations with others are by no means uncommon in Taiwan. The older a woman is, and the poorer and more rural her background, the more likely she is to conduct herself in this way, at least in private. Miss Guo did not live in a village or even a large slum, but in a shrinking enclave of poverty set in what had come to be a fairly fashionable neighborhood. Comfortable 
upper-middle-class condos, superb little restaurants specializing in mainland cuisines, glittering boutiques, and one of the city's newest department stores were only steps away, making her poverty, her thoroughly unbourgeois style, conspicuous.

The squatter neighborhood where Miss Guo, her common-law husband, and about five thousand others live has no name. Land belonging to a wealthy Taiwanese family-their once-elegant ancestral hall still stands, surrounded by the hundreds of tiny make-shift houses-was confiscated for a barracks by the Ministry of National Defense after the Mainlanders arrived in Taiwan. Because the military compound occupied only a part of the land, the remainder soon began to attract squatter residents, at first the households of men stationed at the barracks, and then demobilized men and their families. In recent years, poorer migrants to the city from Taiwan's mountains and countryside have joined the mix. Though the houses have improved over the years in sturdiness and amenities, the density of population may be even greater than in the past. Miss Guo, for example, owns and rents out, to six people, a house with four 5 -foot by 5 -foot bedrooms, an 8 foot by 6 -foot shared dining room and tiny cooking, bathing, and toilet facilities.

Accepting the inevitability of such squatments, Taibei City authorities over the years have provided some water and sewerage to this and the many other slum neighborhoods of the growing city. Each house is marked by the small blue plaque bearing its official address as listed on household registration forms and personal identity cards, slotting it in through bureaucratic procedures as a legitimate residence.

The area is now less noisome and dangerous to health than in 1968, when a large open canal carrying raw sewage and a local commercial specialization in caged watchdogs and dog meat filled the air with stench, mosquitoes, and perpetual, insane barking. The canal is covered, much of the housing has been removed to widen major roads, and the rest will soon disappear under urban renewal.

For the present, it affords Miss Guo a comfortable haven for her eccentricities-a handy base from which to find yet another in her lifelong series of low-paid service jobs, and a network of contacts among those who, like herself, often need a day's work, or a week's loan, or an hour's conviviality.

Guo A Gui told me her life story in the following words.

Look at me, an old bag of fifty-nine who can hardly read a word, telling my life to a scholar. That's a laugh! My whole life I've suffered because I didn't study, and because I'm too fast with my mouth. Being too quick to answer back is something that is just part of my character, I guess. Can't be 


\section{Chinese Working-Class Lives}

helped. But not studying really wasn't my fault. When I was little, I was too lively. Then, in my teens, there was no money for it. At the end of the Japanese period, I was going to get the chance for night school-and the war ended. I lost that opportunity, too, so I'm still a dunce. Even so, maybe my life can be a lesson to young people to study hard, or they will have to live with the bitterness I eat every day.

My father was born in the Dalongdong section of the city, my mother in Sancheng, across the river. Father and Mother opened up rice fields in Dalongdong, farmed them, and sold rice, very respectable sort of work, because everyone depends on farmers. At first, they were quite prosperous, but about the time I was born, they started to lose their business and land. By the time father was dead and buried, when I was six, there was nothing left. Mother had a primary-school education, so she was able to get a job in the Japanese soy-sauce factory that my elder sister and I later worked in. She didn't want to marry again because she was afraid people would laugh at us children for having two fathers. No one with any face likes that idea.

I had an elder brother, who died serving in the Japanese Army in the war, and two elder sisters. Have they been lucky! The older was able to study and get a primary-school graduation certificate, even though she didn't complete all the courses. She married a man with a good job and land, although they lost almost all of it in land reform! Her and her husband's business has prospered so that she's been on a trip around the world. They are respected people. Their neighbors have elected him Neighborhood $\mathrm{Head}^{2}$ many times. Second Elder Sister also married well, and has six sons. Their fortunes have been entirely different from mine.

Even when I was little, I was a mischievous child, always running away. Mother punished me, so I'd run away from her, too. "The farther you run, the more I'll beat you!" she'd say. I can remember running from her, watching her, not daring to go back until she went back in the house, afraid of being beaten. We country kids weren't very well behaved-running away, then sneaking home like thieves.

School was no good for me. I hardly went at all. It was more use to my family, and more interesting for me, to get little jobs harvesting, looking after people's water buffalo, doing things around farms that I could get paid for.

When I was thirteen, and my oldest sister married, our whole household moved with her husband to downtown Taibei. He was an official in the

2. The second lowest-ranked elective office in Taiwan, responsible for liaison between the government and about one hundred neighboring families. 
electric-light bureau, rich enough to take care of us. I found some odd jobs, moving stone or coal for people. It was about that time that elder sister adopted a baby daughter-in-law to marry her son.

When I was fourteen, my second older sister used her influence to get me a job in the soy-sauce factory. Even though I had no primary school certificate-and that factory required education of all its employees-they took me on because she spoke for me. She was a diligent worker for them, very obedient. They even let her live in their dormitory. I worked there till I was nineteen, when the factory closed because of the war.

The factory was a really big one, with each of their sauce vats as big as this room. ${ }^{3}$ There'd be a half-a-year's sauce in there. Above the vats was a mess of piping and gauges. It was awfully dangerous to go up there, because everything was so slippery; if you fell, you'd be dead for sure. No one else dared go up but me-I was young and foolish and had lots of nerve, so I went up to look at temperatures and see how much was left in each vat. Maybe that's why they kept me on as long as they did, because I sure was no model worker!

The place was run in a very orderly way. The couple of hundred people employed-Japanese managers and Japanese and Taiwanese workerswere all expected to arrive promptly at seven, when the bell rang. Anyone who came late was not allowed in, but had to wait till the one o'clock afternoon period began. I'd be scurrying along, barefoot, to get to work on time, jumping into my shoes at the door. (We had to wear shoes to work, but they were so expensive I wore mine only when it was required.) At twelve, when the bell rang, everyone stopped work for an hour's lunch and rest. The factory was very strict, regular, and better-run than factories are now, when people drift in late, goof off during working hours, and have to stay late to finish up. Sundays and holidays we had off.

I earned fifteen $\operatorname{sen}^{4}$ a day, while my sister got twenty. We also got a New

3. About 8 feet by 10 feet.

4. Units of currency used in these life histories vary considerably in value over time; for a complete discussion, see Riggs 1952:103-107. In the 1930s the Taiwanese used the Japanese yen and sen (100 sen to the yen), which began to suffer from inflation after the Pacific War began in 1937. The yen, which had been a fairly stable currency during the earlier decades of the century, rapidly lost value as Japan's production was channeled into the destructiveness of war. When Nationalist authorities arrived to take control of the island after the war, they changed the currency to what soon was to be known as the Old Taiwan dollar, roughly equivalent to the inflated yen of the time. In June 1949, to cope with the rampant inflation brought from the mainland, OT dollars were withdrawn and replaced with New Taiwan dollars, each worth OT $\$ 40,000$. The NT lost value consistently during the $1950 \mathrm{~s}$, although ever more slowly, so inflation of a serious nature persisted over a period of more than twenty years, most of it under Nationalist leadership. 


\section{Chinese Working-Class Lives}

Year's bonus of one month's wages-about five yen. If we were absent for a funeral or for illness, we got half our wages. For absence caused by a workrelated injury, we were paid our usual wage and given money for medical expenses, too. A woman having a baby could have forty days' leave, although she didn't get paid.

I was a playful kid, and found some of their rules hard to obey. Though the factory forbade workers to go around and socialize during working hours, I was alone in that upstairs area, so I got bored. I'd buy cakes and candies from an old Japanese priest who lived near our house to give to friends at work. Once the head of the factory caught me, and he docked me five sen for that day. Worse yet, when the New Year's bonus was distributed, I only got half my bonus. If my sister hadn't pleaded for me, I'd have lost the job. Sister was furious: "How can you mess up right before New Year! Don't you see we're going to be short of money at home because of you, fool!" I think they kept me because I was willing to do the dangerous jobs.

One of the Japanese workers liked to lord it over us. He made only seven yen a month, but he thought he was a big shot, always trying to manage other people's business. When he told me I couldn't rest a moment, even though my work was done, I started to beat him up. We were taken before the special-affairs department of the factory where the dispute was settled in my favor. Even though I was a young girl and a Taiwanese, I had the right of it. The Japanese were reasonable people.

The Japanese were reasonable about most things, but they were fanatics on cleanliness. They wanted the environment kept really clean. For example, vegetable selling on the street was prohibited-it had to be in a market, and the market had to be swept and washed. Streets, privies-they inspected everything. I think they went too far, though, in pushing their way right into people's houses. These were regular inspections where they'd check windows for dirt, and so on, and they'd fine people ten to thirty yen if the house wasn't clean enough!

The Japanese were strict and punished people. They took money from us during the war, because they needed it. Otherwise, they weren't bad. They didn't beat us, or misbehave. They caught criminals effectively, so that

There is no simple way to convert these numbers to current U.S. dollars, and the problem is made yet more difficult because of the drastic difference in living standards and expectations between the present-day United States and the Taiwan of those years. The best measure of change is what a day's manual labor was worth: presumably a small family could survive for a day at least on such wages. Finally, because NT dollars are unofficially tied to the U.S. dollar, Taiwan and the United States have experienced about the same inflation since the 1960 s-over 50 percent. 
there were far fewer thieves and ruffians than there are now. But those house inspections were too much!

The Japanese had their own sections of town, housing clusters for factories and soldiers, and their own markets. They never mixed with us much, and they rarely took Taiwanese women as wives or girlfriends, except for a few waitresses. Taiwanese men didn't marry them either. We all know the reason for this; there's no reason to discuss unpleasant matters. ${ }^{5}$

When the war started, so did the bombing. At the soy-sauce factory, we'd stop work and take cover, then start again. It was very scary. As Taibei's factories were the focus of the bombing, some of them began to move to southern Taiwan, taking their workers with them. My brother-in-law's electricity bureau sent our whole family to Xingang City. Others were sent to Jiayi City. The Japanese took good care of us, providing us with transportation and necessities. We took all our relatives and some of our neighbors. For ordinary Taiwanese who did not work for the Japanese, things were much tougher. Only rich people could afford to flee south.

The Xingang people were good to us. Farmers sent us sweet potatoes, which we boiled and lived on while we were there, for about two months. For those who went to Jiayi, there was a terrible surprise-instead of bombing Taibei, the Americans bombed Jiayi, for two days. They just flattened it, destroying the airport and all factories and institutions. The third day was the day the Japanese surrendered.

We thought we were going to die in Xingang, but through Mazu's ${ }^{6}$ protection, we were saved. Later, Japanese soldiers said that Mazu redirected the bombs that should have fallen on the town so that they fell instead into the harbor. The bottom of the sea exploded, and the fish died, but no people of Xingang, or nearby Beigang, were killed. That is why so many of us Taiwanese worship Mazu since Retrocession.

That is one example of how reasonable religious customs really are; here's another. There is a village in Hong Kong where the people don't eat pork. The reason for that is that long ago, all the adults died, and only one pig was left alive, which nursed all the babies with its milk. Afterward, their descendants wouldn't eat pork out of gratitude to the mother pig. We Taiwanese don't eat beef because cattle work for us so hard and so patiently. So we have our hands behind our backs as far as cattle go. Everything has its explanation.

When we returned home, our house had been burned in the bombing.

5. Chinese often describe Japanese practices in Taiwan as racist.

6. Mazu, the Taiwanese goddess of the sea, has a famous temple in Xingang, and is much revered in that region. 


\section{Chinese Working-Class Lives}

Some paper money we had hidden in the walls was lost, but it didn't really matter. The inflation had begun, and it took a lot of cash to buy just a package of cigarettes. I saved some Japanese coins as souvenirs.

After we returned to Taibei, a friend recommended me for a job in a cake shop, where I stayed a year. I can still make cake, too. My lack of education was no problem there. I was paid according to the number of pastries I made, but I worked so fast that the boss switched me to a harder kind. I was able to make about two hundred yen a day, worth about NT\$2 (U.S.\$0.05) now.

I was still a wild sort of kid. People differ so much-some are reasonable while they're still very young, others don't get sense till they're adults. Take my sister, always so obedient. But me . . . ! Mother was always dissatisfied with me, scolding me for going out to watch Taiwanese opera in the street: "Don't you have to go to work tomorrow? What are you doing, running around so late!" Sometimes when I came in very late, she'd have locked up the house, leaving me outside. Where could I sleep? At last, she'd let me in. My sister didn't go to see opera so often, because she was better educated. That's why I was so wild-no education. When I quarreled with people, they would taunt me, saying, "What kind of education have you had? It was wasted on you!" So some of us end up worse than the rest, and even cleverness is useless. If you lose out on education, you lose everything.

During and after the war, things were very chaotic in Taiwan. There was a period of about a year when the Japanese soldiers fell short of food because the bombing was preventing farmers from growing crops and bringing them to market. The Japanese couldn't help the people, and they couldn't help themselves. The whole island lacked rice, clothes, and medicine. If you got sick, you died.

Right after Retrocession, a lot of Japanese property was claimed by Taiwanese. Some Taiwanese robbed the Japanese, who couldn't put up any resistance-they were the losers. They were insulted and threatened by Taiwanese, too. When we came back to Taibei from Xingang, I was only a young person, but $I$ stopped people from insulting some Japanese, who, after all, were just soldiers sent here by the government. They weren't to blame. In fact, they should be pitied. I gave one soldier a bowl of sweetpotato soup, and, for taking it, his platoon leader beat him up. I felt awful that that terrible beating came from something I had done. I was glad to see the Japanese soldiers being sent back to Japan. If they'd stayed here, they've have died, because there was no food on the island.

After the soldiers from the mainland came, things were very bad; everyone was afraid after Retrocession. Everywhere, their soldiers were out 
attacking Taiwanese women. Girls didn't dare walk on darkened streets or go to work. Things happened to many women. Some died, some got pregnant. Taiwanese men didn't dare resist when Mainlanders insulted Taiwanese women, just as nowadays the Mainlanders still take advantage of us in business. The Japanese were reasonable, and never let that kind of thing go on when they were in power, but now the Mainlanders oppress people and lie to us. When Mainlander soldiers got Taiwanese girls pregnant, their officers didn't order them to marry them.

At that time there were very few Taiwanese prostitutes, because in the Japanese period the government provided soldiers' clubs with Japanese and Korean women for the troops. Taiwanese women were forbidden to be in such places, because the Japanese despised us and would beat up Taiwanese women. The Japanese were very strict-if they wanted you to die, you obeyed. So there weren't many Taiwanese prostitutes. When all those Mainland soldiers came, they just acted as if we were all prostitutes. That's what happened to me, when I was twenty-four. I was too wild, and I became pregnant. At first, I didn't want to marry the man. There was always the chance that the army would counterattack against the Communist bandits, and he'd be sent back to the mainland. But our lives are arranged by fate. My father was dead, my mother said I needed protection. The soldiers had their rice every month, and we had almost nothing.

Then it turned out that he couldn't marry me after all! He was ten years older than I, and already married in his home in Sichuan Province. Lots of mainland soldiers were already married, and married again in Taiwan anyway, but this man's marriage was registered on his military identity card. So we couldn't be formally married. I suppose you could say he's just my boy friend! He had a seventy-seven-year-old mother, a wife, and three sons all left behind. It was a mistake that he was in the army in the first place. His brother was supposed to be taken, but since the brother wasn't home, the recruiters just took him. They put a rope around his neck, dragged him away, and sent him straight to Taiwan.

I'll say this for him, though. He stuck by me after I told him I had his child in my belly. He sent us food and a little money when he could during the years he stayed in the army, when he often had to move to new places.

He never learned Taiwanese, so I talk to him in a kind of Taiwanese Mandarin, and we can communicate. When I speak Taiwanese to him, he listens, and can get the outline of my meaning. He's always been a good cook, preferring his own cooking to mine. The kids used to say, "What Father cooks tastes good, what you cook doesn't." So I've always let him cook.

I continued to live with Mother till she died, about six years after 


\section{Chinese Working-Class Lives}

Retrocession, and with my first elder sister's children whom Mother was taking care of. Sister had eleven children, all brought up by Mother. As each got old enough for school, it would go home to Sister. The last was three when Mother died. Mother took care of my two girls while I worked too. I had to be out by six every morning to reach my job in a cafeteria by seven. It was too far to go home in the hour we had for lunch. Work ended at five, I was home by six, so Mother really had all the responsibility for my two, and several of Sister's, all those years. After Mother died, I still didn't have a son, so I decided to adopt a son from one of my relatives.

In those days, women had their babies at home. When I gave birth the first time, I sent for a midwife. The second time, just a neighbor and Mother helped me-we relied on each other and on experienced people. I didn't have any trouble giving birth, just rested a month before starting work again.

I nursed my babies-everyone did, then. We didn't have powdered cow's milk as today's lucky mothers do. While I was at work, Mother fed the babies rice water with a spoon-no baby bottles with rubber nipples then, either!

I didn't pay any special attention to bringing my children up. Those who are born obedient and reasonable will be obedient and reasonable. It's important to teach them some manners, of course. For example, when a guest comes, I taught them to serve a cup of tea or, if there's no tea, a cup of boiled water, so they'd become accustomed to proper behavior.

There's not so much emphasis on obedience to adults for today's children. Kids used to learn to move when their parents told them to do something. Nowadays, children just go on studying if you tell them to do something, or run off and play. People don't beat their kids anymore, or even dare scold them much.

In 1955 the government made a lot of soldiers who had served for ten years retire, so the five of us moved into this squatter settlement with a lot of other retired mainland soldiers and their wives. Some of the wives were Mainlanders, some Taiwanese, and some even mountain Aborigine women. The land was the government's, no one was living on it, so homeless people came here. The area used to be much bigger-there were a lot of squatters. We built a little house of whatever we could find, carried water from some taps that were put in, and managed as best we could.

It was hard for the children's father to find work in those days. He used to tell me he had been healthy and strong in his youth, but the army life killed his strength. Not enough food, too many diseases. Finally, he got a job cleaning up in the market up the street, the kind of work a lot of old Mainlanders get-cleaning toilets, sweeping up. He and I are pretty well 
matched, born into respectable farm families, but later becoming poor. Couples who differ too much can't be together.

We could have married, in later years, but we never did. Many men who had registered dependents back home arranged to have somebody in Hong Kong mail a letter saying the first wife had died. If we'd done that, we could have married. We wanted to, and I really wanted a husband. But in our hearts, we felt wrong about it. I took off my clothes for him, and had his babies. What was there to fear, really? Just other people's bad mouths. People despise me, but I can still live, talk with friends, have a few laughs. Me and my old lover!

After he retired, he got a few hundred a month from the army-not enough to eat on. He rarely had work, but I've always been willing to work. I worked in restaurants and in people's houses, mostly. Once, I cleaned and washed clothes for a judge's wife. They had a car-really rich people. Mainlanders. I was supposed to get NT $\$ 2,000$ a month for two hours' work every day, but that woman was always cheating me. She'd always want me to stay more than two hours, and though I worked for her for two years, she never raised my wage. At midautumn festival and New Year, she only gave me five hundred, though it is customary to give a month's pay. She picked and complained and found fault. I had to take it-I needed the job. I was born to work all my life. Finally, I quit because she was taking advantage of me. In another job I had with a Mainlander lady, I was paid only thirteen hundred a month, always paid late, and had to listen to the boss talk constantly. I quit her, too, after a while. In a Taiwanese family who ran a wood business I washed and cooked for NT $\$ 1,800$ a month. They were too harsh.

I still have two jobs, getting up at five to sweep streets till nine. I'm considered "needy" by the government, so I was able to get that work. It pays a couple of thousand a month. In the cafeteria, I peel vegetables for two hours every day-that brings in six to seven thousand. I got that through my neighbor, Orchid, who worked there before. Sometimes I substitute for this short-faced kid who works in a restaurant.

Neighbors around here help each other-it's not a bad place to live because of that. People help me get jobs, I help them when they need someone to work for them. We watch each other's houses, take in the laundry if it rains, that kind of thing. One of my neighbors is registered as "poor," a welfare case. She's had a terrible time, so when I have leftover food, I take it over to her. She got used to eating people's leftovers, though these days people are usually too proud to do that. Everybody helps her. After all, it's awful to waste food. We help each other with money, too. I'll pop in on Orchid, and say "Hey, Orchid! Hurry up and lend me three 


\section{Chinese Working-Class Lives}

hundred for a few days" and she does. I'd only do that with a good friend; other people would laugh at me. We don't charge each other interest or anything. Poor people don't do that. It's just for friendship. I run a tab with the little shops in the neighborhood, too, paying when I get paid.

I wouldn't dare borrow from a moneylender who charges interest. The poor, if they want to borrow from the rich, have to persuade them with a lot of ass-kissing talk. If they're flattered, they'll lend-otherwise, not. People like me don't form rotating credit clubs, ${ }^{7}$ either. In those things, you can go broke if the person organizing it gets overextended, or if somebody runs out on his debt. I work myself to death for my money, and can't take the risk. Besides, rich people wouldn't ask us to join their rotating clubs, not if we live in a squatter settlement! And if I had savings-which I don't-I'd put it in the post office or a bank. It's safer.

There are quite a few pawnshops around here, but it's mostly young toughs who go there. I'm bold, but I wouldn't want to be seen going into one-too shameful. Once, when I was so broke there was no money for food, I pawned a coat. I asked someone else to go to the pawnshop for me, though. It was so embarrassing.

People pawn all kinds of things. Motorcycles are always being pawned, though you have to have the owner's registration to prove the bike is your own, not a stolen one. Interest is heavy, about 5 percent a month, in advance, for three months. After that, the pawnbroker gets to keep it if the debt hasn't been paid. Pawnbrokers offer less than the thing is worth, then sell it at a high price, so it's a hard way to get money. Better to go to friends.

There are some rough characters living in this area, especially young ones. Some of them organize gangs, drink, smoke, and get in fights. Occasionally one of them knifes somebody, or one of them gets beaten to death. They seem to go bad during junior high school. If they go bad then, they go bad all the way. The best that can be hoped is that they stay out of jail. They don't bother me, though. I've got nothing to steal, and everyone around here knows me.

Up to five years ago, I had a lot of friends in this neighborhood-nice people, well-off. One lady's husband was a gold jeweler; others had other kinds of shops. They could afford to take trips, go to entertainments, ride on motorcycles. They used to invite me to come along because I made them laugh and have a good time, even if I was poor. They're all gone, now, though, leaving me a lonely old woman.

What happened was that there was a big fire that burned up a lot of the squatters' houses. A lot of my friends moved away. My house was burned,

7. Groups that pool small sums to make unsecured loans to each member in turn. 
too. I dug through the ashes afterward, and found only a few coins I'd saved. I had some gold jewelry, my radio, a lighter, a tape recordereverything went. I had worked so hard to buy that house about a year before. A lot of people were burned out, right in the area where the Taibei City government wanted to build the overpass Orchid's husband is working on. Strange, eh?

I got some disaster relief-a thousand (U.S.\$25) from the local Ward Office, five hundred (U.S.\$12.50) and a piece of clothing for each person from the Guanyin temple by the market, and a hundred and fifty $j i n^{8}$ of rice from the government.

Two months later, I scraped together eighty thousand (U.S.\$2,000) and bought this house. Owning your own is better than renting. There are always squabbles about how to divide up the electric and water charges when you're a renter. It pays me fifteen hundred (U.S.\$37.50) a monthNT $\$ 500$ for each room. A couple of years later, I bought another place behind this one for a hundred thousand (U.S. $\$ 2,500$ ). It has several rooms that I rent out for five thousand (U.S.\$125) a month. These houses are all built on government land, and the whole area is going to be cleared out for modernization in two or three years. I'll get thirty thousand (U.S.\$750) and a small moving fee when it happens, but that's laughable. I guess the best thing for us to do is to move in with my relatives back in Dalongdongthat's where my kids are-and get all the rent I can until I lose my investment here. I've had such terrible luck! Whenever I make any money, fire or the government takes it away!

If my husband had stayed in the army till he was sixty, he would have retired with a good pension and a high rank, like Orchid's. We'd be rich. As it is, he only gets nine hundred a month.

My daughters complain anyway about me living here and working at my age. They're like all my female relatives-good fates, every one of them! My elder brother died in the Japanese Army, and of course my husband has no relatives here, so my sisters' families are all I've got. I've never wanted to let them see how poor I've been, never liked asking them to help me. My daughters didn't work and earn money for me-they just wanted to get married. Their husbands didn't give me bride-price, either. They weren't rich, so I was ashamed to ask for it. My adopted son is not so close to me. There is just me and my old man.

I think my fate was a bad one: born to be a laborer, not getting a bit of the good things of life. I wish there were someone to pity me, but there's not, so I just live like this, keeping independent so others won't despise me. My

8. A jin is approximately one and one-third pounds. 
sisters are rich, but I don't eat their food. I'd lose face. No matter what kind of work I do, I am criticized. Time makes people see clearly, though. After a long time, they will know I've been a good person.

\section{Lo A Lan: The One Who Was Sold}

Mrs. Lo, now in her early sixties, is descended from the Mountain People who inhabited Taiwan before the Chinese came. While there are now perhaps a quarter of a million Mountain People in Taiwan who are recognized as such, many more have, over the centuries, become sinified by learning Chinese languages and customs. Some have melted into the Taiwanese population, which itself is well mixed with mainland minority peoples. Chinese people generally see sinification as a process of cultural betterment, or progress; an Aboriginal background is something to be overcome and to conceal. Mrs. Lo does not think of herself as a Mountain Person, though the Chinese around her do, partly because of her roundeyed appearance, and partly because her original surname, Pan, was taken by many Aborigines as they "became Chinese." She accounts for the differences between her mountain home and the cities of the lowlands in terms of poverty and wealth, insisting she is Chinese.

In a country where most people are relatively short by American standards, Lo A Lan is exceptionally small, a smallness that comes, almost certainly, from childhood starvation. Orphaned, sold, widowed, and left destitute with her children by the time she was thirty, it is no wonder that much of her conversation revolves around food and that her eyes follow automatically when others eat. Her face and hands are calloused, her scarred feet give evidence of the hardness of her life, and she makes no attempt to prettify them. Her early life of "bitter labor" reveals the kind of poverty that many islanders and Mainlanders alike suffered in the early decades of this century. It shows too the special hardness of life for girls and women in rural areas. Lo A Lan's introduction to Taiwan's new Nationalist rulers was the best thing that ever happened to her; she was amused when I suggested that many Taiwanese remembered the prewar days warmly. "Rich people, maybe," she wryly agreed.

It is difficult to believe now that this tiny, aging woman ever had the strength to earn her living as a construction worker and to struggle successfully through to what will probably be a fairly comfortable old age. She seems to have run out of life. Even in lively company, after a drink or two, she looks quiet and tired, though she says her health is good. Although at times she cries over her memories, she shows no anger-and only traces of 
other emotions---at the events of her harsh life. It may be that anxiety will never let her go now, after such long association. Her automatic precautions against want are at once visible in her living room, which is neatly crowded with careful savings: stacks of newspapers, folded paper and plastic bags, hanks of string and rope, sacks of rags, empty glass bottles. When I brought cakes and pastries for her and a friend to eat during our meetings, she would accept nothing, or at most a half piece, though the rest of us nibbled greedily enough. She was too used to bad food, she said, to really enjoy good; it made her uneasy. Perhaps she feared to acquire a taste for things beyond her expectations; perhaps she took more satisfaction in controlling her appetites than she could feel in indulging them.

The house where I sometimes visited her told other things about her. It was built of random pieces of scrap lumber, painted and unpainted, old and new, neatly and securely fashioned into a residence with a small bedroom, a living room, and a tiny, tidy kitchen and bathing room. The separate toilet was shared with the thirty-odd other households that lived in similar motley cottages, laid out in two neat rows, in a field of rubble. They had been built from the fragments of other demolished houses by her husband and the other men of the crew who were constructing an overpass for a major freeway crossing the city.

In front of her house, in the barren subsoil, grew a few undernourished cabbages and leafy greens, and several feeble clumps of flowers. She grew them to make the place look better, she said, but mostly to have something to keep her busy. When she popped in on her friend, Guo A Gui, her conversation was often about work: finding it, losing it, how much she could do, why her husband wouldn't let her take this job or that. Becoming too anxious to sit still, she would pop out again, birdlike, to find some occupation. In moments of quiet, she told me her story.

When I was young, down in the south of Taiwan, there weren't as many people as there are now, and life was very hard. We southerners were worked to death, just to get enough for three meals a day. We were paid so little for our work - just enough to keep alive. People today are much better off. Then, only if we had work that day could we eat that day. In my mother's time, it was bad too. But children now have even become fussy about what they eat: if it's not good-tasting, they won't eat it! Food today's children won't eat was food we never even saw on our table. When I was small, when there was any food at all, I was glad to see it.

We southerners ate mostly sweet potatoes and salt fish. We bought the cheapest little salt fish, boiled them, and drank the soup to give some flavor to boiled sweet potatoes. There are lots of bamboo shoots in the mountains 
to gather. We ate those fresh in season, and preserved some in Japanese sauce and salt for later. Ginger grows well there too. We didn't grow leafy vegetables, and as it took half a day to go down the mountain to market, we never bought any. Very rarely, we would buy ten sen worth of peanuts or bean curd as side dishes. When I was attending school, I ate gruel with a little salt. The other children called me to sit with them, but I would go off by myself to eat, because I was ashamed of what was in my lunchbox. I'd come home and say, "Mother! The other children's food is good. Why is ours so bad?!" She could not answer me. I don't find fault with food now. I'm used to bad food. I can eath both good and bad food.

I am sixty-three now. I was born in the countryside of Tainan county, in the foothills of the mountains in south Taiwan. People planted patches of sweet potatoes in the valleys and collected wood and mountain products for sale. Growing the sweet potatoes was difficult. Farming is always hard, but in the mountains wild pigs come at night and root up the potatoes. Some are bigger than domestic pigs, with sharp tusks-really dangerous. A wild pig was eating our crop one year and ate up a whole field. We predicted that it would move next to another nearby plot, so Father, Uncle, and I dug a deep pit for it. We covered it with bamboo and then with earth. The pig fell right into it. A bunch of us stabbed it with sharpened bamboos to kill it, although it tried to get out and gore us. Its meat was very good, with no fat on it, just real meat. Everyone who had helped kill it got a share of that pig.

In the inner mountains are tigers. We lived in the outer foothills, so we never saw tigers. There was lots of game though-deer, rabbits, and birds. They are all hard to catch, but some men from our mountains were expert hunters.

There were only four families on the mountain we lived on-our family, my uncle's family, and two neighbors. It wasn't like big lowland villages. We had to walk about as far as from here to Taibei Railroad Station ${ }^{9}$ before we came to another little hamlet of three or four families. With the mountains all around, we had to know how to get places, as it was easy to get lost. I was careful to remember that this path went home, that went to a friend's, and so on. Father always went first, and we followed him, learning the way. We didn't dare go out alone when we were little, for fear of not being able to get back. If we had to go by ourselves, we made signs of grasses to point out the road for ourselves.

The land up there belongs to the government, but we really own it. If the government wants it, they must pay for it. We farmed it, but it didn't produce much. Nowadays people even have machines to plow with, but we

9. About three miles. 
pulled the plow ourselves. People left farming whenever they could get work in the lowlands, because it was so unrewarding. Even collecting rubbish or selling tea door to door is better.

My father and all our neighbors were laborers, cutting firewood and bamboo in the mountains, carrying it down on a shoulder pole, and selling it in the plains. There's hardly a flat place to stop to take a breath in, and there are no smooth paths. Every step is hard, and the loads were heavy.

When I was about eight years old, I went to school for a year. The school was a long way from home, down the mountain: if we started at six in the morning, we could reach school by 8:30. But I and the other children really wanted an education. We went every day, even in the rain, and studied diligently. Everything I learned was Japanese, though, so it became useless later.

Our clothes were patched and mended, but that's all right. It was enough that they were clean. Our teachers checked our collars, made sure our hair was neatly cut, and really insisted on good hygiene. Mother's nephew came home from school one day, boasting "The teacher said I was clean, just like rich people!"

Students were required to wear white blouses, but white cloth was not as easy to get as it is now. We used flour sacks, which we had to buy-two for each blouse. We made them ourselves, at night, as there were no readymade clothes then, and we never dreamed of paying a seamstress. We were just glad to get enough cloth.

When I was nine, my mother died, leaving me the eldest of three girls. The others were six and three years old. Without Mother to grow food and care for my sisters, I had to stop studying-I couldn't even afford food, let alone books and tuition! How could I study?

Father left us up on the mountain while he continued as a wood chopper. He'd go and collect a load, carry it slowly down the mountain, sell it, and come back. He'd come home every two or three days. He sold units of one hundred kilos of wood to buyers who came to the foot of the mountain with ox carts. There were different grades of wood, some more expensive, some less. The profit went to the carters, who resold it in town. They paid my father almost nothing. Sometimes Father came back, sometimes he didn't. I had to manage somehow to take care of my sisters. My uncle's family was up there, but they were poor, too. They couldn't help us much. I sighed over my hardships. I washed clothes and cooked; Father kept on chopping on the mountain. Having a strong body is really important in life.

Not long after Mother's death, Father decided to sell us. He sold my sixyear-old sister first, then the three-year-old, then me. They were bought by families who wanted brides for their sons. My first younger sister went to 


\section{Chinese Working-Class Lives}

one of our neighbor families, and remains there to this day. I visit her sometimes, though it's a terribly long journey. The littlest sister is in Tainan.

When I was ten, he sold me, too, to be an adopted daughter-in-law. This is a terrible thing to be, and a pitiful, hard fate to have. My adopted mother was fond of me, so there was some good in it. My husband was about eighteen when I went to live with his family. It was eight years before we began to sleep together. We didn't have a real marriage ceremony, just bowed to Heaven and Earth and to his ancestors, and ate a chicken that my husband brought from down on the plains. He never liked me very much, I don't know why. He didn't beat me, though, because my mother-in-law liked me.

He made our living chopping wood. Sometimes he gambled his money away, sometimes he drank up his earnings. We were always poor. I thought about leaving him and finding a better husband. But how did I know whether another husband would be any better? He might be good, or bad. What would happen to my children if I remarried? The best thing is to be patient and face facts. Young people these days are more willing to divorce. In my time, we just went on and accepted what fate determined for us.

I had three daughters by my husband. Nowadays people think it's necessary to eat fish, rice, and meat after giving birth. When I gave birth to my second daughter, I could only ask my six-year-old to go out to dig some wild vegetables for me. I cleaned them, salted and boiled them, and ate that. People say nowadays that after giving birth a woman should not eat this and that, and should rest. We didn't have such habits. Farmers can't pay attention to all that-there is always work to do. I was out of bed after two or three days, not a month as rich women do. I've known women who had to return to tea picking with newborns on their backs. If you talk about suffering, though, none can compare with mine. I can stand anything.

When my daughters were nine, just under three, and three months old, my husband had been sick for two years, and my mother-in-law had died. I had no money, no one to help me, so I paid my sister to take care of the children and signed onto a labor gang going to Hainan Island. I told her to keep it a secret where I was going, because I thought my husband and my father would stop me.

The Japanese wanted to build new concrete housing for their troops from Taiwan who were stationed on Hainan, because the Communists had blown up the barracks there. The soldiers were all living in tents. Laborers were recruited in the south for this work by a labor contractor who offered us a thousand yen for the trip, twenty yen a day, and money for three meals a day. That was a lot in the Japanese period. The contractor took care of all the 
red tape for us-bought our tickets and arranged for somewhere for us to sleep. There were seven women in our group, but there were men in our labor gang too. Men slept in one room, women in another. I was just over thirty then.

The trip over was frightening. Air raids were beginning in Taiwan, and on the sea we were afraid of being bombed or of hitting a mine. The trip took ten days, with all of us seasick most of the time. It was interesting to arrive in Hainan, though. I had never been anywhere away from our mountains. There were a lot of new things to see. The food was very good in Hainan. We ate rice every day, and good fish. Although carrying concrete was bitter labor, I felt better than I felt at home. My strength improved.

Suddenly, though, I felt unwell. I decided to go home for a visit, and asked the labor chief for permission. He reminded me that my contract was for a year, but he was kind and gave me and another woman tickets to go back. I promised I would come back in a few days, leaving without even taking my clothes.

After I got home, though, my sister asked me to delay a while so we could both make offerings to Mother's spirit on the anniversary of her death. I waited. When I tried to return to Hainan, I learned that the Communist bandits had captured Hainan, so I couldn't go there and the others couldn't come back! We two were fortunate to have come back, as otherwise we would have died. But it was impossible to get my thousand yen.

I stayed on the mountain with my children until after the Retrocession. In about 1947 my uncle took two bamboo baskets and went to Tainan City to collect rubbish and scrap iron to sell. As he found he could earn enough to buy food, he came back and suggested that we leave the mountain. I was very doubtful. I knew nothing of Tainan. What if we starved to death? But he said we could collect scrap and live! Father wouldn't leave the mountain, but my sisters and I came down.

We worked for a boss, who rented us a three-wheeled cart for the scrap and a room to live in. We gave what we collected to him, and he paid us, deducting rent for the room and the cart. We built a stove by ourselves in our room with concrete.

In the morning, Uncle and I started collecting about dawn. When we started, the boss gave us three yen for breakfast, which was plenty. We worked till eleven, and he gave me forty or fifty sen for lunch. After lunch, I went out again until six o'clock, when the boss gave me another two yen. We ate rice and fish and vegetables, and I even had money left over.

This work wasn't hard. We were eating, and one of my sisters stayed home with all the children. But this work is only for the most useless, 


\section{Chinese Working-Class Lives}

lowest kind of people. I had to go through garbage, even through the contents of privies. People despised us.

My husband joined us in Tainan, but he was still too sick to work. He was with us a few months before he died. We borrowed money and buried him.

I got a job as a construction laborer, earning ten yen a day for carrying baskets of earth, concrete, and sand on a shoulder pole. When men laborers dug out the foundations, I carried the earth to carts. When they mixed concrete, I brought them sand. When the concrete was ready, I carried it to the forms and poured it in. That was hard work. I still have trouble with my legs and back from it. My sister took care of the children, and I paid her so we could all live.

Then things became really bad for me. In 1947 there was a lot of trouble between us Taiwanese and the soldiers. It was bad for business. I worked less. When the 2:28 troubles were over, it was harder for me to get a job because there were more men looking for work. I have a small body, and though I am strong for my size, I can't compete with men in carrying things. My sister was afraid of starvation, so she took her children and went back to the mountain. There was no one to care for my children, no work, and no food. My children cried for sweet potatoes, remembering how in the mountains we could just go to the fields and dig them. Here, though, I thought of going out into the countryside at night to steal food. I was afraid, but sometimes I had to do it anyway. There are people who don't mind telling the world they're without food, begging for it. I wouldn't do that. I kept my problems to myself, giving everything I could get to the children. The one thing I was determined not to do was to sell my girls, or even put them out to work in labor gangs. If only I could get enough food for us!

We had no place to live, so we moved into an unused air-raid shelter. The people in charge were not supposed to let vagrants live there, but they took pity on me, and turned a blind eye. Some days I got work. When I had more money, I bought more; with less money, I bought less. I bought the smallest, cheapest sweet potatoes, and the smallest, oldest fish. The children ate the fish, and sometimes I ate nothing. I had only one pot to cook in, and it was so thin and cheap that the salt from cooking corroded through it. How ashamed I felt to live like this, to try to raise my kids in such a makeshift way! But I told myself to be patient and to accept that this was my bad fate. I wouldn't let myself be angry with the children. It was not their fault. If I had been angry with them, I would have sold them long ago. It was my responsibility to bring them up into adults. My own mother and my adopted mother had died, leaving me to grow up by myself. I would not leave my daughters.

In 1948 I found work washing clothes at a military camp outside Tainan. I 
worked there, doing all kinds of odd jobs for the soldiers for five years. When I first went to work there, the soldiers were the "62" troops-young boys, fifteen or sixteen years old, who had been shanghaied into the army when they were caught on the road somewhere. They weren't proper soldiers, just kids, really. They got two meals a day at our camp, at ten for breakfast, and five for dinner, usually getting coarse rice, bean waste, and peanuts. There wasn't much leftover food at that camp! These troops stayed in Taiwan for a year, then they were discarded, sent back to fight on the Mainland. They were replaced by the Youth Army, all junior and senior high school graduates, officers, and good soldiers. Things improved. Three days after they arrived, one of their cooks gave me the head and tail of a pig! It was a real feast for my children.

The Youth Army was divided into nine groups. I lived in the third, working for them and groups one and two for four years. Everyone treated me kindly, and called me "Goodlooking." "Hey, Goodlooking! Come! Here's some food for you." They gave me all the heads and internal organs of the pigs they ate. Having been so poor, I was glad just for ordinary food, but this was something special. The men ate rice and were given clothes, and I got these too.

The officers were always calling me "Hey! Goodlooking! I want to give you some food. You can't eat it all? Take it home to your kids." "Goodlooking! Come! My shirt needs mending. Would you do me a favor and sew it up? You have no thread? Take this money to buy some." We laughed and joked during those years. That's how I learned Mandarin. Otherwise, where would I go to study how to speak it?

When visiting big brass came to give out gift packages of clothes and canned goods, the officers told me to stand in rank with the short soldiers, so I got some too. After we were dismissed, a couple of the soldiers asked me for the clothing-it was for men, of course. I gave them the puttees but kept the rest of the uniform to make over for myself and my family. I got a share in the regular army distribution of rice, salt, oil, and fuel which all soldiers get. When they killed pigs to celebrate midautumn festival and lunar New Year, I got that too. That was the first time in a long time my family had celebrated the holidays. Although the troops were always good to me, I had to be a bit careful with the officers, try to figure out their moods. Sometimes the officers got all worked up and yelled at me; sometimes they were kind. The higher officers were gentlemen-they knew how to behave. It was the lower ones who were trouble. They would try to bother us women sometimes. I was always careful not to be alone with them.

Once, when the troops were preparing for a combat mission, an officer 


\section{Chinese Working-Class Lives}

announced that everyone must get his photo for his identity badge renewed. He told me to get a new one, too, saying, "Your picture isn't very attractive. Get dressed up tomorrow, and go take a better picture." I said, "I've got no money for that. What does it matter to me if my picture is goodlooking or not?"

He insisted on giving me money for a dress, even though I refused several times. When I got my new picture, he asked me for a copy, and wanted to give me one of his. I asked him why he wanted my picture. At that time, he was to be sent somewhere to fight-maybe back to the mainland, maybe to somewhere in Taiwan-I can't remember now. He said that when he looked at my picture, he would remember our acquaintanceship here in Tainan, and hoped I would remember him, too. Maybe he was afraid he might die in the fighting.

Anyway, the troops came back the next night, all but two who were killed. They were all so happy to be safe they got some liquor and called me to drink with them. "Old woman, Good-looking, bottoms up! I toast you! Everybody's back safe!" We drank one cup after another, toasting all around.

The arrival of the Youth Army from China was a really good thing for me, much better than the "62" troops. Some of them were from families that were well-to-do on the mainland. They were deceived into thinking they would be allowed to study if they came here, but they became soldiers instead. The training was tough, and they considered the food very coarse. Really, their situation wasn't so bad, I thought. It was just like ordinary people's lives. When some of them cried over their fate, others comforted them, saying, "It's not so bad. You'll get used to it." Even if they didn't get used to it, they had no choice, because they could never go back home. Things turned out pretty well for most of them. They nearly all married women here and have families. At that time, considering how poor everyone was, women were glad to marry them.

My present husband, Old Lo, is a retired soldier, though not from that group of educated youth. We were introduced by a soldier in the camp I worked in after I had been washing clothes for the army for nearly five years. He wanted to marry because he had been fighting for many years and he missed home life. Now that there was peace in Taiwan, he wanted to start a family. My friends told him I was hard-working and did not complain about difficulties.

I thought hard about marrying him, trying to decide if it would be good for me and my daughters. At that time, many soldiers were being retired against their will. Some were too old, or too young, or too sick, or too stupid. The country didn't want to pay them. So many men looking for 
work! But my husband was still in the army. He was a war hero who had been shot in the fighting. They had operated on him to remove the bullets, and he recovered, as good as new. He was considered to have made real contributions to the country. I thought, "Maybe it will be bad to marry this man, as it was with my first husband. Maybe not. If I stay single, I cannot improve life for my children. If I marry and he is bad to us, I can leave him and support myself again. The children are mine. He cannot take them."

Also, I liked his appearance. He is a strong man and very capable. He can speak Cantonese, Shandongnese, some other dialects, even Japanese. He learned Taiwanese, too. So I agreed to marry him, and I became "Mrs. Lo."

For the next few years, my husband was transferred a lot from place to place. I followed him, with my children, staying wherever the army arranged-in railroad stations, in schools, in temples, sometimes in little lean-tos beside buildings. We carried cooking pots and bedding and managed the best we could. We wives helped each other, because the men were in their camps most of the time. I worked whenever I could, to earn money for my children. The army gave us rice, salt, oil, and fuel, but almost no money. Though I tried to send them to school, we were rarely in the same place very long. They couldn't study well. Then they sent him to Pingdong, where we stayed for ten years. He sometimes went away for several months, because his work then was building the government's roads in the mountains. But we had a house in an army "new village." Things were better. My two oldest daughters married soldiers, too, men much older than themselves, and my youngest was able to complete elementary school. The schools for army children are not so good, but at least she learned to read.

In 1967, when my husband was fifty-five, he was permitted to retire from the army and join the government's engineering company that employs only veterans. He has done this ever since. His job requires him to live near the roads he is helping to build. Right now, we have lived for a year beside this squatter settlement where the Taibei City government is building an overpass. From the materials from the houses torn down for the right-of-way, the construction crew built our houses. There are about forty families living here, all older retired soldiers. Most have wives, some Taiwanese, some mainland women. My husband knows the other men because they work together, but I only know a few women. So I work to keep busy, doing washing and growing vegetables in our yard. We'll be here another year or so. Who knows where we'll go next?

When my husband is sixty-five, he will retire again, and we will get a lump sum to live on. We get paid enough to live on every month- 
NT $\$ 9,000.00$ (U.S. $\$ 225$ ). Depending on length of service, people get three or four hundred thousand, or a million. My husband has a long period of service, about fourteen years. The office of the president sent him a plate of green marble on a recent anniversary of Retrocession to honor his contributions, and he gets a platinum ring every year as a gift. Our rent is only NT $\$ 500$ (U.S. $\$ 12.50$ ) a month, very low these days.

We probably have enough money, but I am used to working. I've worked in families as a servant, in restaurants, and most recently I do laundry wherever we go, because my husband gets angry when I work outside. I feel anxious when I don't have work.

My daughters and youngest sister are in the south, my other sister in the mountains. I see them occasionally. For next month's national election, our company has given both my husband and me railroad tickets back to Pingdong, where we are registered, so we can vote to support the party. At that time, I will visit my relatives and see my grandchildren.

My husband wanted to have children of his own, but I never became pregnant with his child. I know there is nothing wrong with my body, because I had five children altogether-two died after my first daughter. He raised my daughters like his own children, always treating them well. They call him "Father." I am grateful to him. 